\title{
SALAT JUMAT DARING DALAM PERSPEKTIF HUKUM ISLAM
}

\section{FRIDAY PRAYERS ONLINE IN THE PERSPECTIVE OF ISLAMIC LAW}

\author{
Fakhrizal Idris
}

Basaer Asia Publishing Jakarta

faris.albiruny@gmail.com

\section{Muhammad Yusram}

Sekolah Tinggi Ilmu Islam dan Bahasa Arab (STIBA) Makassar

yusrananshar@stiba.ac.id

\section{Azwar Iskandar}

Sekolah Tinggi Ilmu Islam dan Bahasa Arab (STIBA) Makassar

azwar.iskandar@gmail.com

\begin{tabular}{|c|c|}
\hline Keywords : & ABSTRACT \\
\hline $\begin{array}{l}\text { Friday prayers, Islamic law, } \\
\text { Legal, Online, Perspective }\end{array}$ & $\begin{array}{l}\text { This study aims to: (i) know the valid requirements of Friday } \\
\text { prayers; and (ii) analyze the validity of Friday prayers by online } \\
\text { from the perspective of Islamic law. This research is qualitative } \\
\text { descriptive research with library study techniques and theological- } \\
\text { normative (syar'i) and philosophical approaches. The results of } \\
\text { study show that: (i) Friday prayer is a mandatory worship based } \\
\text { on the Qur'an, Sunnah and ijmak, which have the pillars and } \\
\text { conditions that must be observed for the sake of validity; (ii) the } \\
\text { implementation of Friday prayers y online is invalid. At least this } \\
\text { can be reviewed from two aspects; first, aspects of the basic } \\
\text { principles and objectives derived from Islamic sharia (maqasid al- } \\
\text { syari'ah), where keeping Friday prayers in accordance with the } \\
\text { Sunnah of the Prophet Muhammad saw. became part of hifzu al- } \\
\text { din (keeping religion) so that it should not change the pattern of } \\
\text { Friday prayer that the original law is a whole building. Islamic } \\
\text { law has given rukhsah for every Muslim who is obliged to pray } \\
\text { Friday prayer to replace it with Zuhr prayer when there is } \\
\text { something that prevents it; second, the aspect of Islamic } \\
\text { jurisprudence review, where Friday prayers require the existence } \\
\text { of prayer congregations and is not validly performed individually. } \\
\text { Analogizing online Friday prayers with online marriage contracts } \\
\text { is incorrect because the law of kias must be analogous to the } \\
\text { original law that has direct evidence and should not be to legal } \\
\text { products or other kias results. }\end{array}$ \\
\hline \multirow{2}{*}{$\begin{array}{l}\text { Kata kunci : } \\
\text { Daring, Hukum Islam, Sah, } \\
\text { Salat Jumat, Perspektif. }\end{array}$} & ABSTRAK \\
\hline & 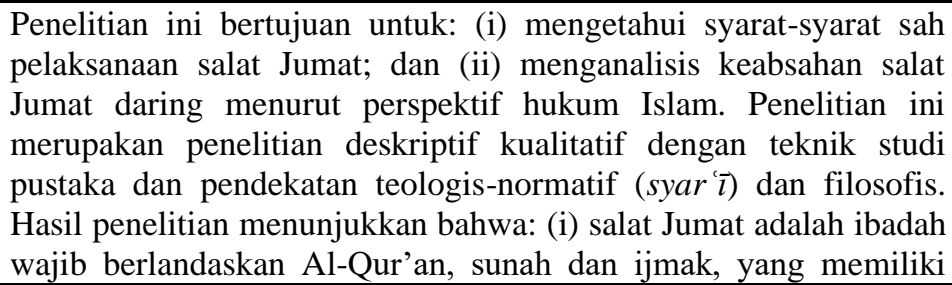 \\
\hline
\end{tabular}




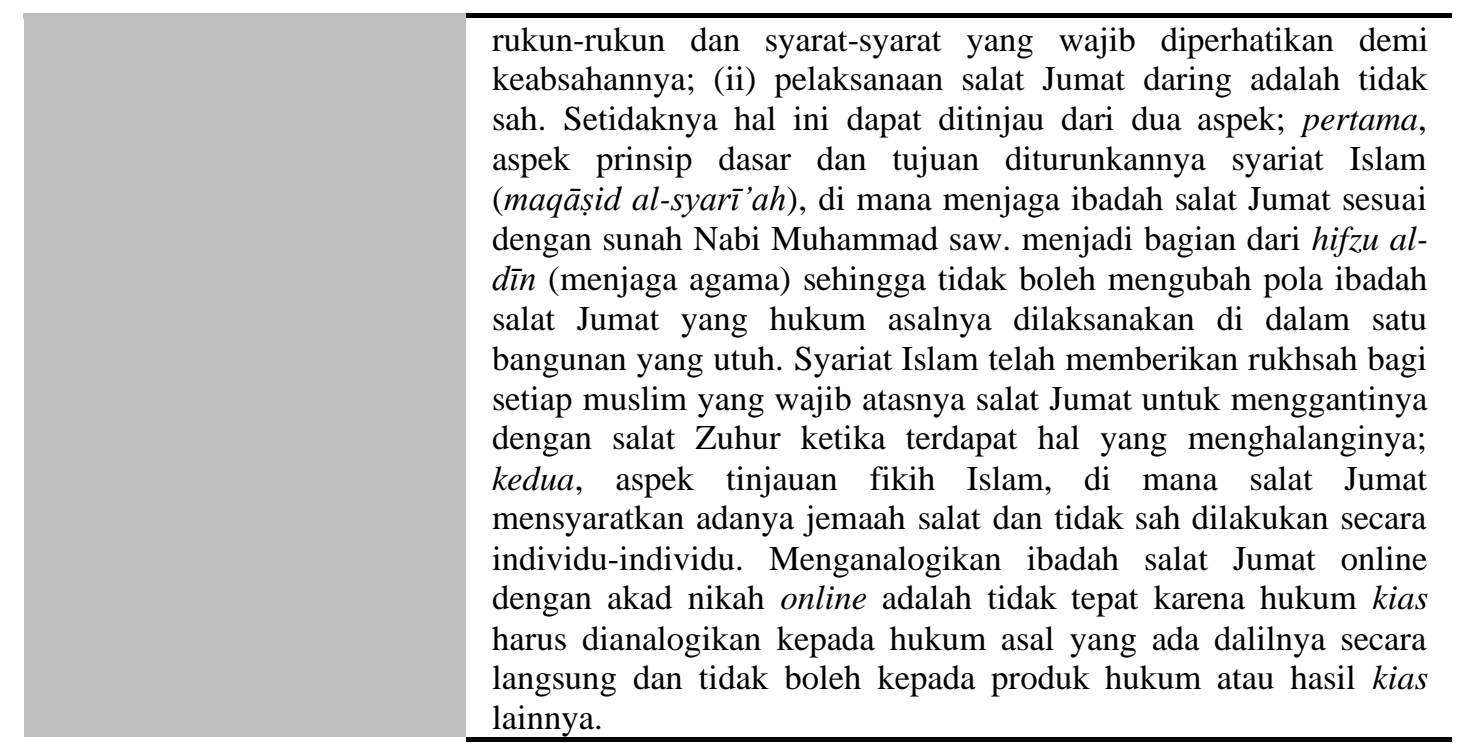

Diterima: 21 April 2021; Direvisi: 22 April 2021; Disetujui: 22 April 2021; Tersedia online: 23 April 2021

How to cite: Idris, Fakhrizal., Muhammad Yusram and Azwar Iskandar, "Salat Jumat Daring dalam Perspektif Hukum Islam", BUSTANUL FUQAHA: Jurnal Bidang Hukum Islam 1, No.2 (April 23, 2021): 110-129. https://doi.org/10.36701/bustanul.v2i1.326

\section{PENDAHULUAN}

Pelaksanaan salat Jumat dalam jaringan (daring) saat ini telah menjadi alternatif oleh sebagian komunitas masyarakat baik di dalam maupun luar negeri. ${ }^{1}$ Hal ini menyusul adanya penyebaran wabah corona virus desease (COVID-19) sejak akhir tahun 2019 M dan merebak secara global di tahun 2020. Di antara bentuk upaya yang diserukan dan dilakukan oleh dunia, termasuk Indonesia, dalam rangka mengurangi penyebaran wabah ini adalah dengan kebijakan social atau physical distancing. ${ }^{2}$ Seluruh bentuk kegiatan keagamaan dan sosial kemasyarakatan dianjurkan untuk dilakukan secara daring untuk menghindari kerumunan karena berpotensi tinggi terhadap penularan virus. Seluruh komponen masyarakat sangat dianjurkan untuk menjaga jarak, menjaga kebersihan anggota tubuh yang rentan menjadi media penularan virus dan mengenakan atribut tertentu sebagai upaya pencegahan seperti masker.

Praktik pelaksanaan salat Jumat secara daring di tengah pandemi sudah dilakukan oleh sebagian komunitas di Indonesia sejak tanggal 29 Mei 2020 melalui aplikasi Zoom Virtual Meeting sebagaimana yang termaktub dalam undangan yang disebar melalui

\footnotetext{
${ }^{1}$ Kumparan News, Pro dan Kontra di Sejumlah Negara soal Salat Jumat Online, https://kumparan.com/kumparannews/pro-dan-kontra-di-sejumlah-negara-soal-salat-jumat-online-1uuaGwQjgf5. Diakses pada tanggal 25 Maret 2021.

2 Azwar Iskandar, Bayu Taufiq Possumah, dan Khaerul Aqbar, "Peran Ekonomi dan Keuangan Sosial Islam saat Pandemi Covid-19," SALAM: Jurnal Sosial dan Budaya Syar-i 7, no. 7 (2020): 625-638.
} 


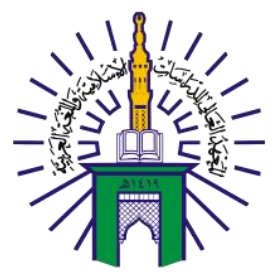

\section{BUSTANUL FUQAHA: \\ JURNAL BIDANG HUKUM ISLAM \\ Vol. 2 No. 1 (2021): Hal. 110-129 \\ EISSN: 2723-6021 \\ Website: https://journal.stiba.ac.id}

jejaring media sosial. ${ }^{3}$ Komunitas tersebut menamakan panitia pelaksana kegiatan sebagai takmir masjid online dan mendiskripsikan pengurus masjid daring tersebut sebagai pihak yang "sabar dan cerdas" dalam upaya merawat dan mengembangkan proyek mulia dan penuh solusi. ${ }^{4}$ Pihak penyelenggara juga terus memublikasikan dan mengampanyekan kegiatan mereka serta menghimbau agar umat Islam tidak melaksanakan ibadah di masjid.

Islam adalah agama yang selalu memberikan solusi dan kemudahan bagi manusia secara umum dan bagi setiap muslim secara khusus dalam melaksanakan ibadah dan muamalah baik dalam kondisi normal atau lapang maupun sulit atau darurat. Ibadah dan muamalah adalah dua hal yang tidak dapat dipisahkan, namun antara keduanya ada perbedaan yang mesti dikaji dan dipahami.

Tidak melakukan interaksi langsung dan menghindari percampuran fisik ketika wabah merebak (sebenarnya) merupakan solusi nabawi yang telah dipraktikkan sejak ribuan tahun lalu. Ketika khalifah Umar bin al-Khatthab melakukan perjalanan ke negeri Syam dan rombongan tiba di wilayah Sargh, para pemuka dan pemimpin di negeri Syam di antaranya Abu Ubaidah bin al-Jarrah menemui Sang Khalifah. Abu Ubaidah bin al-Jarrah menginformasikan bahwa di negeri Syam telah muncul dan merebak wabah. Anggota rombongan kekhalifahan tersebut berbeda pandangan, apakah mereka akan terus melanjutkan perjalanan atau sebaliknya kembali ke kota Madinah. Umar bin al-Khatthab sebagai pemimpin tertinggi saat itu memandang perlu untuk melakukan musyawarah. Sesi pertama musyawarah dilakukan oleh khalifah bersama kaum Muhajirin. Sesi kedua musyawarah, dilakukan oleh khalifah Umar bin alKhatthab bersama kaum Ansar. Kemudian setelah itu, sesi dengar pendapat dengan para pemuka Quraisy dan orang-orang yang berislam pada waktu penaklukan kota Makkah. Dalam musyawarah ini, para pemuka kaum Quraisy berpendapat bahwa rombongan disarankan untuk kembali dan tidak melanjutkan perjalanan. Keputusan tersebut tidak sejalan dengan masukan kaum Muhajirin, namun Abdurrahman bin Auf kemudian menyampaikan bahwa Nabi Muhammad pernah bersabda,

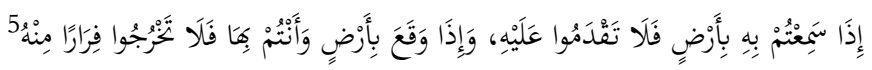

Artinya:

"Jika kalian mendengar wabah di suatu negeri maka jangan kalian mendatanginya. Jika wabah terjadi di suatu negeri, kalian berada didalamnya maka jangan kalian keluar lari darinya." (H.R. al-Bukhari).

Melakukan dialog dan bermusyawarah dalam menyikapi permasalahan kontemporer yang dihadapi kaum muslimin adalah metode klasik yang masih sangat

\footnotetext{
Kompas TV, Ikhtiar Salat Jumat Online di Tengah Pandemi, https://www.kompas.tv/article/148623/ikhtiar-salat-jumat-online-di-tengah-pandemi, diakses pada tanggal 25 Maret 2021.

${ }^{4}$ Ibid.

${ }^{5}$ H.R. Al-Bukhari, al-Jāmi' al-Sahih, vol. 7, (Beirut: Dar Thuq an-Najaah, 1422 H), no. 5729, 130.
} 


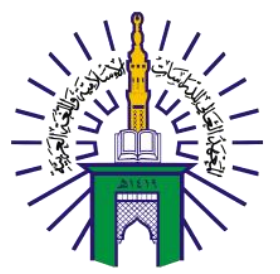

\section{BUSTANUL FUQAHA: \\ JURNAL BIDANG HUKUM ISLAM \\ Vol. 2 No. 1 (2021): Hal. 110-129 \\ EISSN: 2723-6021 \\ Website: https://journal.stiba.ac.id}

relevan untuk diterapkan. Para ulama sebagai ululamri atau satu dari dua komponen yang tidak dapat dipisahkan dari istilah 'ululamri' mesti menjadi rujukan dalam setiap permasalahan dalam lingkup fikih al-nawāzil atau permasalahan kontemporer yang membutuhkan ijtihad, terutama jika tidak ada nas yang menjelaskan permasalahan tersebut secara eksplisit atau detail.

Imam al-Nawawi melakukan istinbat dari kisah dialog antara Abu Bakar dan Umar bin al-Khatthab serta para sahabat lainnya terkait persoalan kaum Arab yang menolak membayar zakat kepada khalifah Abu Bakar sepeninggal Rasulullah bahwa para ulama berijtihad terkait permasalahan kontemporer dan mengembalikannya kepada pondasi asal dinul-Islam 6 . Hal tersebut selaras dengan manhaj ilahi, Allah swt. berfirman,

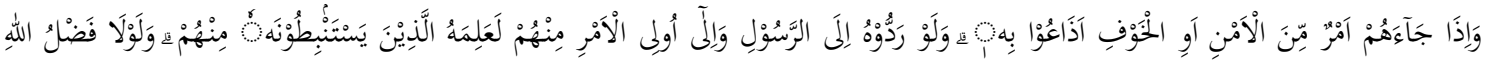

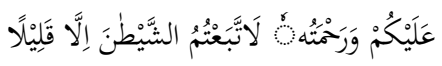

Terjemahnya:

"Dan apabila sampai kepada mereka suatu berita tentang keamanan ataupun ketakutan, mereka (langsung) menyiarkannya. (Padahal) apabila mereka menyerahkannya kepada Rasul dan Ulil Amri di antara mereka, tentulah orangorang yang ingin mengetahui kebenarannya (akan dapat) mengetahuinya (secara resmi) dari mereka (Rasul dan Ulil Amri). Sekiranya bukan karena karunia dan rahmat Allah kepadamu, tentulah kamu mengikuti setan, kecuali sebagian kecil saja (di antara kamu)". (Q.S. al-Nisa': 83).

Pelaksanaan salat Jumat secara daring seperti yang dikemukakan di atas sesungguhnya merupakan salah satu fenomena terkini yang patut untuk dicermati, khususnya dalam perspektif hukum Islam. Hal ini karena secara formal, pelaksanaan salat Jumat harus memenuhi syarat-syarat sahnya, sebagaimana yang telah dicontohkan oleh Nabi Muhammad saw. dan dirumuskan oleh para ulama mujtahid. Syarat yang terpenuhi akan mengantarkan ibadah salat Jumat kepada tujuan yang diinginkan oleh syariat. Pertanyaan yang muncul kemudian adalah apakah salat Jumat secara daring tersebut telah memenuhi syarat-syarat salat Jumat seperti yang dituntukan oleh agama Islam? Al-Qur'an dan hadis sebagai landasan dalil ibadah dan panduan dalam bermuamalah, sangat relevan untuk terus dikaji untuk merumuskan prinsip-prinsip ibadah dan panduan dalam bermuamalah. Keberadaan manusia dipermukaan bumi menjadikan mereka subjek aktif dalam menghadapi perubahan dalam perannya melaksanakan tugas memakmurkan bumi dengan sebenar-benarnya. Oleh karenanya, setiap muslim wajib memahami situasi di mana dia melaksanakan ibadah dan di mana dia menjalankan muamalah serta perbedaan antara keduanya dan sisi persamaannya.

${ }^{6}$ Al-Nawawi, al-Minhaj Syarh Shahih Muslim bin al-Hajjaj, vol. 1 (Beirut: Dar Ihya at-Turats al-Arabi, $1392 \mathrm{H}), 213$. 
Berangkat dari uraian di atas, penting untuk melihat dan mengkaji lebih jauh bagaimana tinjauan hukum Islam terhadap pelaksanaan salat Jumat secara daring. Beberapa penelitian terdahulu telah mencoba untuk mengkaji beberapa permasalahan ibadah terkait dengan kondisi pandemi COVID-19, seperti yang dilakukan oleh Syandri dan Fadhlan Akbar ${ }^{7}$, Eko Misbahuddin Hasibuan dan Muhammad Yusram ${ }^{8}$, Ronny Mahmuddin, et. al. ${ }^{9}$, Mukran H. Usman, et. al. ${ }^{10}$, Muhammad Yusram ${ }^{11}$, Aswanto Muhammad Takwi Hede, et. al. ${ }^{12}$, Sirajuddin, et. al ${ }^{13}$, Ahmad Hanafi Dain Yunta ${ }^{14}$, Sudirman dan Muhammad Rusdi Rasyid ${ }^{15}$, Hudzaifah Achmad Qotadah ${ }^{16}$, Shubhan Shodiq $^{17}$, Muhammad Kumaidi ${ }^{18}$, dan lainnya. Pada umumnya penelitian-penelitian tersebut memiliki kesamaan dari sisi kajian analisis hukum Islam yaitu pada suatu persoalan kontemporer, di antaranya berupa pembahasan tentang hukum peniadaan suatu ibadah atau aktifitas karena adanya pandemi berdasarkan perspektif maqāsid alsyarī'ah, kaidah-kaidah fikih dan usul fikih semisal kaedah al-masyaqqah tajlib altaisìr, al-ḍarar yuzāl, dan lā yunkaru tagayyur al-ahkām bitagayyuri al-azmān wa al$a h w a \bar{a} l$. Namun demikian, jika dilihat dari sisi objek kajian, penelitian-penelitian terdahulu tersebut belum mengkaji hukum salat Jumat daring ini secara khusus sehingga perlu untuk mengkajinya secara khusus pula sebagai bagian dalam pengayaan khazanah

7 Syandri dan Fadhlan Akbar, "Penggunaan Masker Penutup Wajah Saat Salat Sebagai Langkah Pencegahan Wabah Coronavirus Covid-19," SALAM: Jurnal Sosial dan Budaya Syar-i 7, no. 3 (2020): 261-268.

${ }^{8}$ Eko Misbahuddin Hasibuan, dan Muhammad Yusram, "Hukum Salat Berjemaah Di Masjid Dengan Saf Terpisah Karena Wabah,” BUSTANUL FUQAHA: Jurnal Bidang Hukum Islam 1 no. 2 (2020): 106-24.

9 Ronny Mahmuddin, Irsyad Rafi, Khaerul Aqbar, dan Azwar Iskandar, "Hukum Menyegerakan Penyerahan Zakat Harta Dan Zakat Fitrah Di Saat Pandemi Covid-19," BUSTANUL FUQAHA: Jurnal Bidang Hukum Islam 1 no. 2 (2020): 125-36.

${ }^{10}$ Mukran H. Usman, Aswar Aswar, and Zulfiah Sam, "Covid-19 Dalam Perjalanan Akhir Zaman: Sebab, Dampak Dan Anjuran Syariat Dalam Menghadapinya," BUSTANUL FUQAHA: Jurnal Bidang Hukum Islam 1 no. 2 (2020):137-55.

${ }^{11}$ Muhammad Yusram, “Azan dan Kaifiatnya di Tengah Wabah Covid-19,” BUSTANUL FUQAHA: Jurnal Bidang Hukum Islam 1 no. 2 (2020): 174-96.

12 Aswanto Muhammad Takwi Hede, Rachmat bin Badani Tempo, dan Irsyad Rafi, "Hukum Pelaksanaan Salat Tarawih Di Rumah Karena Wabah dan Membaca Al-Qur'an Melalui Mushaf dan HP Ketika Salat”. BUSTANUL FUQAHA: Jurnal Bidang Hukum Islam 1 no. 2 (2020): 251-61.

${ }^{13}$ Sirajuddin, Kasjim Salenda, dan Abdul Wahid Haddade, "Peniadaan Salat Jumat Dalam Surat Edaran Gubernur Sulsel Nomor: 451.11/2057/2020 Selama Pandemi Covid-19 Perspektif Maqāșid AlSyarīah," NUKHBATUL 'ULUM: Jurnal Bidang Kajian Islam 6 no. 2 (2020): 289-309.

${ }^{14}$ Akhmad Hanafi Dain Yunta, dan Asri, "Hukum Melaksanakan Salat Id Secara Personal (Munfarid) (Sebuah Solusi Pelaksanaan Salat Id Di Masa Wabah Covid-19)," BUSTANUL FUQAHA: Jurnal Bidang Hukum Islam 1 no. 2 (2020): 262-71.

${ }^{15}$ Sudirman dan Muhammad Rusdi Rasyid, "Resolusi Maqasid al-Syariah Terhadap Penanggulangan Virus Covid-19," Tasamuh: Jurnal Studi Islam 12, No. 2 (2020): 253-431.

16 Hudzaifah Achmad Qotadah, "Covid-19: Tinjauan Maqasid Al-Shariah Terhadap Penangguhan Pelaksanaan Ibadah Shalat di Tempat Ibadah (Hifdz al-Nafs Lebih Utama Dari Hifdzal-Din?)," Salam: Jurnal Sosial dan Budaya Syar-i 7, No.7 (2020): 659-672.

${ }_{17}$ Shubhan Shodiq, "Penanganan Covid-19 Dalam Pendekatan Kaidah Fikih dan Ushul Fikih: Analisis Kebijakan Pembatasan Sosial Berskala Besar di Biang Keagamaan,” Jurnal: al-Adalah: Jurnal Hukum dan Politik Islam 5, No. 2 (2020): 113-134.

${ }^{18}$ Muhammad Kumaidi, "Implementasi Kaedah La yunkaru tagayyur al-ahkām bi tagayyuri al-ahkām wa al-Ah\}wāl Dalam Ibadah di Masa Pandemi”, Asas 1, No. 01 (2020): 65-82. 
Islam dan kontribusi bagi umat khususnya dalam menyikapi setiap pola ibadah yang tidak sesuai dengan tuntunan syariat dan menyelisihi fatwa ulama yang muktabar.

Oleh karena itu, penelitian ini dilakukan dengan tujuan untuk: (i) mengetahui syarat-syarat sah pelaksanaan ibadah salat Jumat; dan (ii) menganalisis keabsahan salat Jumat secara daring menurut perspektif hukum Islam. Didasari pada pertimbangan luasnya masalah yang berkaitan dengan tujuan penelitian tersebut, maka kajian ini hanya dibatasi pada pembahasan mengenai syarat-syarat yang harus dipenuhi dalam pelaksanaan salat Jumat dan keabsahannya berdasarkan perspektif Al-Quran dan tafsirnya, hadis nabawi dan syarahnya, maqāsid al-syarī'ah sebagai falsafah yang paling mendasar dalam pembentukan syariat Islam $^{19}$ dan turunannya yang bersifat aldarūriyyah.

Berdasarkan tujuan yang hendak dicapai, penelitian ini termasuk ke dalam kategori penelitian deskriptif yang bertujuan untuk menggambarkan situasi atau gejala tertentu secara terperinci. ${ }^{20}$ Dari sisi pendekatan, penelitian ini merupakan penelitian kualitatif melalui teknik studi pustaka ${ }^{21}$ dengan pendekatan teologis-normatif ( syar $^{(} \vec{\imath}$ ) dan filosofis. Sumber data yang digunakan berupa data sekunder yang diperoleh dari beberapa sumber seperti ayat-ayat Al-Qur'an, hadis-hadis Nabi saw. dan teori-teori maqūṣid al-syarī'ah dari kitab-kitab para ulama (kitab turāts) berupa literatur-literatur yang berfungsi dalam interpretasi ayat dan hadis, karya-karya ilmiah yang yang terkait dengan objek penelitian, hasil-hasil penelitian, jurnal ilmiah, media cetak maupun media online. Adapun langkah-langkah yang dilakukan dalam pengolahan data penelitian yaitu: (1) mengumpulkan data dan mengklasifikasikan teori-teori atau literatur-literatur ilmiah yang relevan dengan ojek kajian dan ilmu maqāșid al-syarī'ah, khususnya dalam kitab al-Muwāfaqāt karya Imām al-Syāțib̄̄, karena komunitas yang melaksanakan praktik salat Jumat daring menjadikannya sebagai hujah; (2) mengimplementasikan nas-nas yang bersifat teori terhadap objek kajian dan mengikatnya dengan interpretasi ulama.

\section{PEMBAHASAN}

\section{Makna Salat Jumat dan Hukum Pelaksanaannya}

Salat Jumat adalah ibadah wajib berlandaskan Al-Quran, sunah dan ijmak. Dalil dari Al-Quran adalah firman Allah Ta'ala,

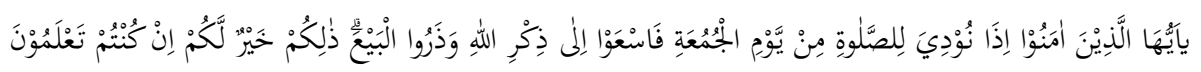

Terjemahnya:

19 Sirajuddin, Sirajuddin, Kasjim Salenda, and Abdul Wahid Haddade. 2020. "Peniadaan Salat Jumat Dalam Surat Edaran Gubernur Sulsel Nomor: 451.11/2057/2020 Selama Pandemi Covid-19 Perspektif Maqāṣid AlSyarīah”. NUKHBATUL 'ULUM: Jurnal Bidang Kajian Islam 6 (2), 289-309.

${ }^{20}$ Bambang Sudaryana, Metode Penelitian, (Yogyakarta: Deepublish, 2017 M), 9. Pelajar, 2013).

${ }^{21}$ John, W. C., Research Design Pendekatan Kualitatif, Kuantitatif dan Mixed, (Yogyakarta: Pustaka 
"Wahai orang-orang yang beriman! Apabila telah diseru untuk melaksanakan salat pada hari Jum'at, maka segeralah kamu mengingat Allah dan tinggalkanlah jual beli. Yang demikian itu lebih baik bagimu jika kamu mengetahui.” (Q.S. al-Jumu'ah: 9)

Kata فَاسنْعَوْ bermakna 'segeralah' adalah kata perintah dan perintah syariat hukum asalnya wajib. Dalil dari hadis nabawi antara lain,

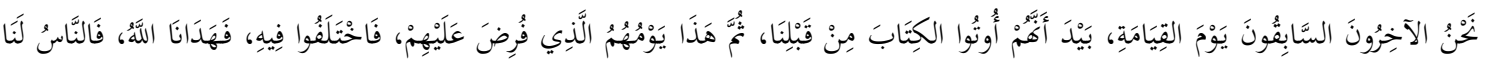

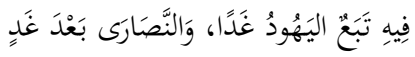

Terjemahnya:

"Kita (umat) terakhir namun pertama (masuk surga) pada hari kiamat, meskipun mereka diberi kitab sebelum kita. Dan ini adalah hari di mana diwajibkan atas mereka (untuk melaksanakan ibadah), namun kemudian mereka berselisih di dalamnya (penentuan hari tersebut). Allah lalu memberi hidayah (menyimpan hari tersebut) untuk kita, maka semua manusia akan mengikuti kita, besok hari untuk Yahudi dan Nasrani hari setelahnya lagi",22.

Imam al-Syafi'i menukilkan ijmak dari generasi ke generasi kaum muslimin tentang kewajiban salat Jumat sebagaimana validnya penukilan kewajiban empat rakaat salat Zuhur ${ }^{23}$. Mengingat bahwa salat Jumat hukumnya fardu ain sebagaimana salat fardu lima waktu, maka salat Jumat harus memenuhi rukun-rukun dan syarat-syaratnya. Ada tambahan yang merupakan kekhususan salat Jumat antara lain: dipersyaratkan halhal tambahan untuk keabsahannya, dipersyaratkan untuk menentukan siapa yang wajib melaksanakannya, dan adab-adab yang disyariatkan dalam pelaksanaannya ${ }^{24}$.

\section{Praktik Salat Jumat Daring di Indonesia dan Luar Negeri}

Salat Jumat online berdasarkan praktik yang telah dilakukan oleh sebagian komunitas di Indonesia dalam beberapa waktu belakangan ini adalah dengan melaksanakan khotbah dan salat Jumat secara online atau dalam jaringan (daring) melalui aplikasi zoom, video conference, web conference, atau aplikasi yang berbeda, namun dengan prinsip kerja yang sama yaitu penggunaan teknologi informasi berupa perangkat keras seperti laptop, kumputer dan smartphone melalui jaringan internet. Praktik ibadah tersebut dilakukan dengan alasan keamanan diri dari penyebaran/penularan COVID-19.

Ada dua prinsip dasar yang dijadikan alasan oleh pihak penyelenggara salat Jumat Online. Pertama, prinsip penegakan maqāṣid al-syarī'ah yaitu menjaga keselamatan jiwa (hifzu al-nafs). Kedua, sikap antisipatif menghindari virus yang

${ }^{22}$ Muhammad bin Ismail al-Bukhari, Sahih al-Bukhari, vol 2, hadis no. 876, h 2. Muslim bin al-Hajjaj alNaisaburi, Sahih Muslim, vol 2, hadis no. 855, 586.

${ }^{23}$ Muhammad bin Idris al-Syafi'i, al-Umm, vol. 1 (Beirut, Darul Makrifah, 1991 M), 217.

${ }^{24}$ Al-Nawawi, Raudhatu at-Thalibin wa Umdatu al-Muftiin, vol. 2 (Cet. III. Beirut, al-Maktab Al-Islamiy, $1991 \mathrm{M}), 10$. 


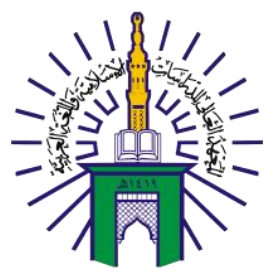

\section{BUSTANUL FUQAHA: \\ JURNAL BIDANG HUKUM ISLAM \\ Vol. 2 No. 1 (2021): Hal. 110-129 \\ EISSN: 2723-6021 \\ Website: https://journal.stiba.ac.id}

sedang merebak ada dikerumunan jemaah. Hal tersebut dianggap lebih baik daripada sikap kuratif, menunggu jatuhnya korban ${ }^{25}$.

Landasan dalil yang digunakan sebagai hujah komunitas tersebut dalam pelaksanaan salat Jumat online antara lain ${ }^{26}$ :

1. hadis Nabi saw. yang menyebutkan bolehnya menjadikan semua permukaan bumi sebagai tempat salat (masjid) dan suci.

2. menganalogikannya dengan akad nikah online yang disaksikan oleh banyak orang padahal ia adalah peristiwa sacral.

3. kitab al-Iqna' karya Ahmad bin Muhammad bin al-Shiddiq al-Ghumari (dipublikasikan sekitar tahun 1375 Hijriah atau tahun 1960 Masehi) yang menegaskan keabsahan salat Jumat di rumah di depan radio, mengingat bahwa inti dari pelaksanaan Jumat adalah khotbah.

4. ilustrasi dari Ibnu Qudamah tentang sahnya salat jemaah meskipun makmum dan imam terpisah dengan sungai yang luas, selama suara imam dapat dipastikan terdengar.

Sementara sebagian pihak dari luar Indonesia juga ada yang berfatwa tentang dibolehkannya salat Jumat virtual selama masa pandemi, ketika masjid-masjid harus ditutup dan dibatasi dari salat berjemaah serta menggemukakannya sebagai hukum dalam kondisi darurat. Di antaranya adalah Syekh Muhammad al-Hasan al-Dadow. Namun demikian, perlu dicermati dengan saksama bahwa praktik salat Jumat dengan fasilitas radio dan televisi seperti yang dibolehkan oleh penulis kitab al-Iqna' dan fatwa Syekh Muhammad al-Hasan al-Dadow, yaitu makmum atau jemaah mengikuti imam atau khatib Jumat yang berada di masjid. Adapun bentuk praktik salat Jumat daring di Indonesia selama masa pandemi adalah berbeda di mana imam dan jemaah seluruhnya berada di rumah.

Landasan fatwa penulis kitab al-Iqna' dan dalil yang dikemukakan oleh Syekh Muhammad al-Hasan al-Dadow adalah sama dan serupa bahkan penulis kitab al-Iqna' mengemukakan dalil yang lebih banyak. Semua dalil dan hujah tersebut dapat dirangkum sebagai berikut:

Pertama, sahnya salat makmum di luar masjid ketika dia mengikuti imam yang ada di dalam masjid. Dalil yang dikemukakan adalah hadis yang diriwayatkan dari Aisyah,

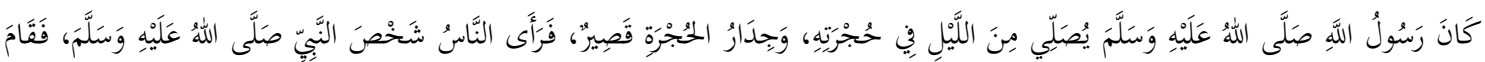

$$
\begin{aligned}
& 27
\end{aligned}
$$

Terjemahnya:

\footnotetext{
${ }^{25}$ Kumparan, Praktik Salat Jumat Online di Indonesia, https://kumparan.com/kumparannews/praktik-salatjumat-online-di-indonesia-1uvr0MIjMt3/full, diakses pada tanggal 25 Maret 2021.

${ }^{26} \mathrm{Ibid}$.

${ }^{27}$ Muhammad bin Ismail al-Bukhari, Sahih al-Bukhari, vol 1, hadis no. 729, h 146. Muslim bin al-Hajjaj alNaisaburi, Sahih Muslim, vol 1, hadis no. 781, 539.
} 


\section{BUSTANUL FUQAHA: \\ JURNAL BIDANG HUKUM ISLAM \\ Vol. 2 No. 1 (2021): Hal. 110-129 \\ EISSN: 2723-6021 \\ Website: https://journal.stiba.ac.id}

"Pada suatu malam Rasulullah pernah salat di kamarnya, dinding kamar beliau cukup rendah hingga orang-orang pun melihat sosok Nabi saw. Orang-orang pun berdiri dan shalat bermakmum kepada beliau." (HR. al-Bukhari dan Muslim).

Kemudian dinukilkan pula fatwa Imam Malik pada kitab al-Mudawwanah bahwa salat di serambi masjid adalah sah. Menurutnya, boleh melaksanakan salat Jumat di serambi dan halaman masjid, toko-toko dan rumah-rumah yang boleh dimasuki tanpa perlu izin meskipun tidak bersambung saf-saf dengan serambi (masjid) tersebut. Bahkan jika bangunan-bangunan tersebut dipisahkan dengan jalan, siapa yang salat di situ maka salatnya sempurna (sah) jika masjid tidak lagi mampu menampung (jemaah) ${ }^{28}$ Pada pasal ini, semua fatwa dan penjelasan ulama yang disebut penulis kitab tersebut dikaitkan dengan kondisi masjid yang sudah penuh dan tidak lagi menampung jemaah. Syekh Muhammad al-Hasan al-Dadow juga menyebutkan fatwa-fatwa yang sama dari kitab 'al-Mudawwanah' yang berisi fatwa-fatwa dan pendapat fikih dari Imam Malik tersebut.

Kedua, sahnya salat Jumat di tempat yang jauh dari masjid (tempat asal salat Jumat) yang dia ikuti dalam satu kota. Argumen yang diberikan penulis kitab adalah jika salat Jumat boleh dilakukan di luar masjid dalam jarak dekat, maka itu adalah dalil untuk yang jaraknya jauh. Hal ini karena tidak ada perbedaan antara jarak dekat dan jauh selama suara imam dapat didengar dan memungkinkan mengikutinya melalui radio.

Dalil yang kemudian dilekatkan dengan pasal ini adalah hadis Ibnu Abbas ketika beliau memerintahkan muazin saat hujan untuk mengucapkan "Salatlah di rumah kalian" dan beliau menyandarkan hal tersebut dari perbuatan Nabi Muhammad, di mana Nabi memerintahkan orang-orang untuk salat di rumah dan di tempat mereka masingmasing ketika kondisi hujan. Kemudian penulis kitab menegaskan bahwa jika perintah untuk salat di rumah ketika salat Subuh maka salat yang dilakukan di rumah tentu Salat subuh. Jika perintah untuk salat di rumah ketika salat Zuhur maka yang dilaksanakan orang-orang tentu salat Zuhur pula. Dengan demikian, apa yang menghalangi ketika waktu Jumat orang-orang untuk kemudian melaksanakan salat Jumat di rumah mereka? .29

Ketiga, sah salat Jumat dengan radio di kota yang berbeda dalam satu negeri.

Pada pembahasan ini, penulis beralasan bahwa Kota Madinah pada masa Nabi Muhammad dan masa hidup penulis berbeda luasnya. Tidak ada dalil pembatasan wilayah dengan jarak tertentu sehingga tetap sah mengikuti salat Jumat dari kota lainnya dengan fasilitas radio tersebut. Dalil yang disebutkan pada pasal ini adalah bagaimana

${ }^{28}$ Ahmad bin Muhammad bin as-Siddiq, al-Iqna 'bissihah Salatil Jum'ah fil Manzil Khalfa al-Midzyaa', (Darul Ta`lif, 1375 H), 33.

${ }^{29}$ Ahmad bin Muhammad bin as-Siddiq, al-Iqna 'bissihah Salatil Jum'ah fil Manzil Khalfa al-Midzyaa', (Darul Ta`lif, 1375 H), 40. 


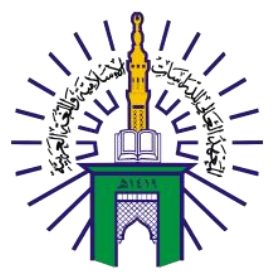

\section{BUSTANUL FUQAHA: \\ JURNAL BIDANG HUKUM ISLAM \\ Vol. 2 No. 1 (2021): Hal. 110-129 \\ EISSN: 2723-6021 \\ Website: https://journal.stiba.ac.id}

malaikat ikut serta mengaminkan salat kaum muslimin yang salat di bumi sedangkan para malaikat tersebut berada di langit. Nabi Muhammad bersabda,

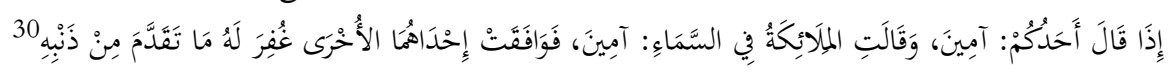

Terjemahnya:

“Jika seseorang mengucapkan 'amin', malaikat di langit akan berkata, 'amin'.

Jika berbarengan antara keduanya, maka akan dihapuskan semua dosanya yang lalu." (HR. al-Bukhari dan Muslim).

Demikian ringkasan dalil-dalil dan argumen yang disampaikan oleh pihak luar Indonesia yang membolehkan salat Jumat secara virtual.

\section{Keabsahan Praktik Salat Jumat Daring dalam Perspektif Hukum Islam \\ Aspek Prinsip Dasar dan Tujuan Diturunkannya Syariat Islam (Maqāṣid Al- Syarī'ah)}

Menjaga keselamatan jiwa adalah adalah satu dari maqāșid al-syarí'ah yang bersifat al-darūriyyah yang maknanya adalah sesuatu yang harus dan mesti ada dalam upaya penegakan maslahat dinul-Islam dan perkara duniawi. Menjaga dinul-Islam terkait pokok ibadah seperti, iman, kalimat syahadat, salat, zakat puasa dan haji. Sementara menjaga keberlangsungan jiwa dan akal adalah pokok 'adāt (adat), seperti makan, minum, pakaian dan tempat tinggal, untuk menjaga keberlangsungan jiwa dan akal manusia ${ }^{31}$. Imam al-Syāṭibī meringkas pembahasannya dengan berkata,

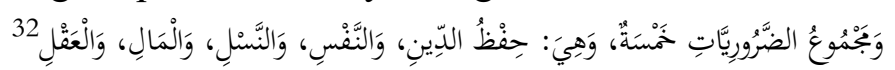

Terjemahnya:

"Lima hal al-darūriyyāt (esensial) adalah menjaga al-dīn (agama), jiwa, keturunan, harta dan akal."

Menjaga ibadah salat sesuai dengan sunah Nabi Muhammad saw. menjadi bagian dari hifzu al-dīn (menjaga agama). Hal ini karena salat Jumat adalah ibadah mahdah (khusus) yang harus ada teladan dan contoh spesifik dari Nabi Muhammad saw. Oleh karenanya, tidak tepat jika ada yang berupaya mengubah pola ibadah salat Jumat yang hukum asalnya dilaksanakan di dalam satu bangunan yang utuh, dalam hal ini adalah masjid, menjadi terpisah-pisah dengan jarak yang berjauhan lebih jauh dari jarak sebuah sungai yang luas.

Lebih dari 1400 tahun yang lalu sebelum COVID-19 mewabah, syariat Islam telah memberikan rukhsah bagi setiap muslim yang wajib atasnya salat Jumat untuk menggantinya dengan salat Zuhur sebanyak empat rakaat dan tidak perlu berkumpul dengan orang banyak ketika terdapat hal yang menghalanginya. Rukhsah ini berlaku ketika seseorang atau sekumpulan orang merasa khawatir akan keselamatan jiwa

\footnotetext{
${ }^{30}$ Muhammad bin Ismail al-Bukhari, Sahih al-Bukhari, vol 1, hadis no. 781, h 156. Muslim bin al-Hajjaj alNaisaburi, Sahih Muslim, vol 1, hadis no. 410, 307.

${ }^{31}$ Ibrahīm ibn Mūsa al-Garnāṭī al-Syatibi, al-Muwafaqat, vol. 2 (Cet. I, Dar Ibnu Affan, 1997 H), 19.

${ }^{32}$ Ibid.
} 


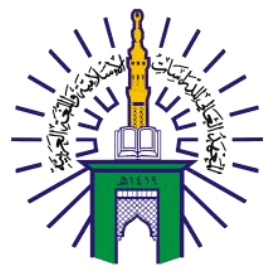

\section{BUSTANUL FUQAHA: \\ JURNAL BIDANG HUKUM ISLAM \\ Vol. 2 No. 1 (2021): Hal. 110-129 \\ EISSN: 2723-6021 \\ Website: https://journal.stiba.ac.id}

mereka, baik karena kondisi safar, sakit, wabah, atau bahkan takut kepada penagih utang padahal dia belum mampu membayarnya. Dalam sebuah riwayat dari Ibnu Qudāmah al-Maqdisī, dikatakan bahwa Nabi saw. tidak mengerjakan salat Jumat ketika safar pada pelaksanaan haji wadā' yang bertepatan dengan hari Jumat, di mana Nabi menjamak salat Zuhur dan Asar di Arafah tanpa mengerjakan salat Jumat. ${ }^{33}$

Dengan adanya rukhsah ini, dapat dipahami bahwa syariat salat Jumat berada pada kualifikasi mukammil (komplemen) dari syariat salat lima waktu yang merupakan syariat asalnya. Dalam teori maqāṣsid al-syarī'ah, Imām al-Syāṭibī, berkata tentang tujuan diturunkannya syariat Islam bahwa,

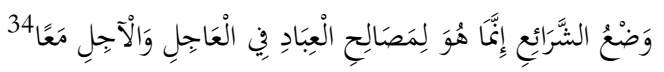

Terjemahnya:

"Pembentukan syariat, hakikatnya adalah untuk kemaslahatan manusia di dunia sekaligus di akhirat."

Menurutnya, maqāṣ̦id fī al-tasyrī' atau hikmah dalam pembentukan setiap syariat adalah,

Terjemahnya:

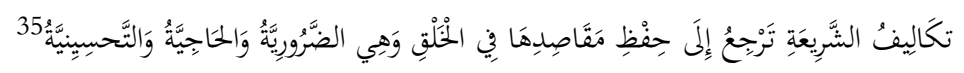

"Segala takālīf (beban) syariat berorientasi untuk menjaga maqāṣid -nya terhadap manusia yaitu kemaslahatan yang bersifat ḍarūri (primer), hạajī (sekunder) dan tahsīn̄i (tersier)".

Kemaslahatan yang bersifat tersier (tahsiniyyah) ini adalah penyempurna dari kemaslahatan sekunder, dan kemaslahatan sekunder ( $h \bar{a} j \bar{j})$ adalah penyempurna dari kemaslahatan primer. Dengan kata lain, kemaslahatan tersier dan sekunder ibarat anggota badan (al-ṣifah) bagi tubuh (al-maușüf) yang merupakan kemaslahatan primer, sehingga kemaslahatan al-hājiyyah dan al-taḥsiniyyah yang hanya berperan sebagai pelengkap tidak boleh didahulukan jika dapat mengakibatkan kemudaratan terhadap kemaslahatan al-darūriyyah ${ }^{36}$. Kedua jenis kemaslahatan al-häjiyyah (sekunder) dan altahsīniyyah (tersier) bagaikan pelindung yang melingkari kemaslahatan al-darüriyyah (primer). Inilah yang diistilahkan oleh al- al-Syāțibi dengan al-maqāṣid al-kulliyyah dalam maqāṣid al-syarī ah. Imam al-Syāṭibi berkata,

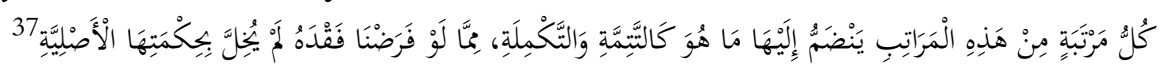

Terjemahnya:

"Setiap tingkatan pada kualifikasi maqāșid tersebut terdapat di dalamnya maqāșid yang bersifat pelengkap (hâjji dan taḥsīn $\bar{l}$ ), yang jika diumpamakan

\footnotetext{
33، Abdullah ibn Ahmad ibn Qudāmah al-Maqdisī, al-Mugnī, Jilid.2 (t.t; Maktabah al-Qāhirah, 1968), dalam al-Maktabah al-Syāmilah ver. 3.62 [CD ROM], Muassasah al-Maktabah al-Syāmilah, 2008, 250.

${ }^{34}$ Ibrāhīm ibn Mūsa al-Garnāṭī al-Syatibī, al-Muwāfaqūt, Jilid. 2 (Cet. II; al-Riyād\}: Dār ibn al-Qayyim li al-Nasyr wa al-Tauzī', 2006), 9.

${ }^{35}$ Ibrāhīm ibn Mūsa. Al-Garnāțī al-Syatibī, al-Muwāfaqāt, Jilid. 2, 17.

${ }^{36}$ Ibrahīm ibn Mūsa al-Garnāțī al-Syatibi, al-Muwāfaqāt, Jilid 2, 25.

${ }^{37}$ Ibrāhīm ibn Mūsa al-Garnāțī al-Syatibi, al-Muwāfaqāt, Jilid 2, 24.
} 


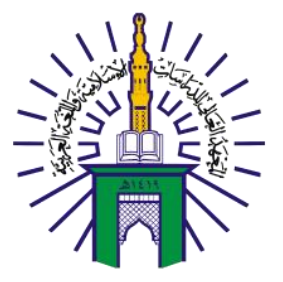

\section{BUSTANUL FUQAHA: \\ JURNAL BIDANG HUKUM ISLAM \\ Vol. 2 No. 1 (2021): Hal. 110-129 \\ EISSN: 2723-6021 \\ Website: https://journal.stiba.ac.id}

pelengkap tersebut hilang maka hal itu tidak akan menyebabkan hilangnya asal syariat tersebut".

Imam al-Syațibī menyebutkan sebuah teori dalam menyikapi dua maqāṣid yang kontradiksi bahwa,

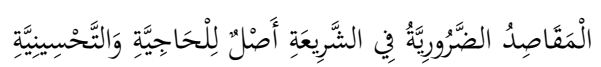

Terjemahnya:

"Al-Maqāṣid al-ḍarūriyyah dalam syariat adalah pokok dari (maqāṣid) alhājiyyah dan al-tahsininiyyah" (pelengkap) ${ }^{38}$.

Jika maqāṣid al-hājiyyah dan al-taḥsiniyyah adalah komplemen bagi maqāṣid al-darūriyyah, maka keduanya tidak boleh didahulukan jika berpotensi menghilangkan kemaslahatan asal yang lebih utama, dalam hal ini adalah maslahat utama keselamatan jiwa manusia. Muhammad ibn Husain al-Jīzān̄̄ berkata ketika menjelaskan kaedah alal-Syațibī tersebut,

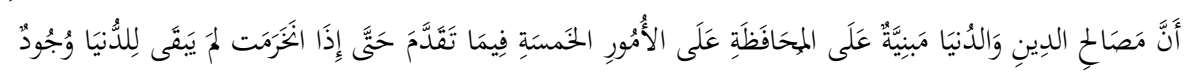

Terjemahnya:

"Bahwa kemaslahatan agama dan kemaslahatan duniawi dibangun di atas pemeliharaan al-darüriyyāt al-khams sebagaimana yang telah disebutkan, yang jika diibaratkan kemaslahatan itu hilang maka dunia pun akan ikut hilang"39.

Dari ucapan tersebut dapat dipahami bahwa segala hukum syariat baik yang berupa perintah maupun larangan berorientasi menjaga dan melestarikan kemaslahatan al-ḍarūriyyāt al-khams, sehingga jika terjadi kontradiksi antara dua maqāṣid atau kemaslahatan, maka yang didahulukan adalah kemaslahatan yang mengarah kepada pelestariannya, bukan yang meniadakannya. Walhasil, jika pelaksanaan salat Jumat yang merupakan maqāṣid mukammil (pelengkap) dari pokok ibadah salat lima waktu dapat membahayakan eksistensi jiwa yang merupakan maqāṣid al-ḍarūriyyāh, maka salat Jumat boleh ditiadakan dan diganti dengan salat Zuhur di rumah hingga situasi kembali normal. Tidak perlu melaksanakan salat Jumat secara daring sebagai pengganti salah Jumat secara normal.

\section{Aspek Tinjauan Fikih Islam}

Imam al-Nawawi menyebutkan syarat sah pelaksanaan salat Jumat antara lain:

1. Waktu, yaitu waktu salat Zuhur, di mana jika waktunya telah keluar atau tidak mencukupi untuk melaksanakan dua khotbah dan dua rakaat salatnya, maka salat Jumat tidak boleh dilaksanakan dan wajib diganti dengan salat zuhur.

2. Negeri bermukim, yaitu kota dan desa yang ditempati secara permanen.

3. Adanya jemaah salat, yaitu salat Jumat tidak sah dilakukan secara individuindividu, karena syarat yang harus dipenuhi dalam salat berjemaah berlaku pula

\footnotetext{
${ }^{38}$ Ibrāhīm ibn Mūsa al-Garnāṭ̄ al-Syatibī, al-Muwāfaqāt, Jilid. 2, 31.

${ }^{39}$ Muhammad ibn Husain al-Jizani, Tahzib al-Muwafaqat (Cet. III; al-Dammam: Dar ibn al-Jauzi, 1430), 118.
} 


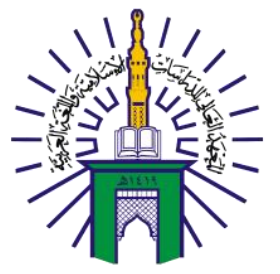

\section{BUSTANUL FUQAHA: \\ JURNAL BIDANG HUKUM ISLAM \\ Vol. 2 No. 1 (2021): Hal. 110-129 \\ EISSN: 2723-6021 \\ Website: https://journal.stiba.ac.id}

pada salat Jumat, antara lain: imam dan makmun berada pada satu tempat secara hakiki ${ }^{40}$.

Syarat terakhir ini tidak dapat dipenuhi dalam pelaksanaan salat Jumat daring yaitu imam dan makmum dalam satu tempat dan bukan sendiri-sendiri di tempat yang berjauhan.

Salat Jumat adalah ibadah yang secara spesifik ditetapkan untuk mengagungkan Allah Ta'āla dan menggapai rida-Nya atau diistilahkan dengan ibadah maḥdah. Contoh ibadah mahdah (khusus) lainnya adalah zikir, puasa dan ibadah haji. Tidak tepat jika menganalogikan atau mengiaskan ibadah salat Jumat online dengan akad nikah online (seperti yang telah disinggung sebelumnya). Nikah bukan ibadah maḥ̆ah. Nikah dan segenap atributnya adalah muamalah dan urusan yang prinsip dasarnya adalah keberlangsungan kehidupan dan manfaat duniawi. Amalan yang demikian akan bernilai ibadah jika secara khusus dibarengi dengan niat pelakunya dan dilaksanakan dengan tata cara sesuai syariat.

Pengunaan dalil kias dalam penetapan keabsahan hukum salat Jumat online dengan akad nikah online adalah tidak tepat. Hal ini karena hukum kias harus dianalogikan kepada hukum asal yang ada dalilnya secara langsung dan tidak boleh kepada produk hukum atau hasil kias lainnya. Contohnya, sahnya hukum kias tentang keabsahan membayar zakat fitri dengan beras setelah dikiaskan kepada kurma, dengan ilat bahwa keduanya adalah bahan makanan pokok, sebagaimana dimaklumi ada dalil langsung perintah untuk mengeluarkan zakat fitri dengan kurma atau gandum. Adapun akad nikah online, tidak ada dalil langsung yang menyebutkan keabsahannya. Ia adalah produk hukum dan hasil ijtihad, sehingga tidak boleh posisinya dijadikan hukum dasar untuk melekatkan kesimpulan hukum kias. Begitu juga, argumen bahwa inti salat Jumat adalah mendengarkan khotbah adalah tidak tepat, karena syarat sah salat Jumat bukan hanya pelaksanaan dan mendengarkan khotbah saja, sebagaimana telah disebutkan.

Seluruh bumi adalah suci dan boleh dijadikan tempat sujud dan masjid, ini adalah kekhususan dari Allah Ta'āla kepada Nabi Muhammad saw., selaras dengan sabda beliau,

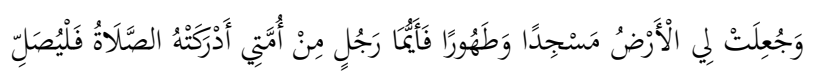

Terjemahnya:

"Dijadikan bumi untukku sebagai masjid (tempat sujud) dan (boleh untuk) suci, sehingga di mana saja salah seorang dari umatku mendapati waktu salat, hendaklah ia salat." 41

Hadis tersebut secara eksplisit menyebutkan bolehnya salat di mana saja selama dapat dipastikan tempat sujudnya bersih dari najis, termasuk salat di rumah masingmasing. Dari hadis ini dapat diketahui pula, tidak ada lafaz dalam hadis yang

${ }^{40}$ Al-Nawawi, Raudhatu at-Thalibin wa Umdatu al-Muftiin, vol. 2 (Cet. III. Beirut, al-Maktab Al-Islamiy, $1991 \mathrm{M}), 13$.

${ }^{41}$ Muhammad bin Ismail al-Bukhari, Sahih al-Bukhari, vol 1, hadis no. 323, 74. 


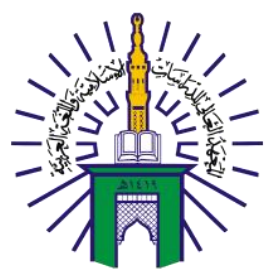

\section{BUSTANUL FUQAHA: \\ JURNAL BIDANG HUKUM ISLAM \\ Vol. 2 No. 1 (2021): Hal. 110-129 \\ EISSN: 2723-6021 \\ Website: https://journal.stiba.ac.id}

menyatakan sahnya salat berjemaah atau salat Jumat sejumlah orang dengan kondisi setiap individu di tempat berbeda-beda atau bumi yang berbeda-beda.

Adapun dalil yang disebutkan oleh penulis kitab al-Iqna' yaitu,

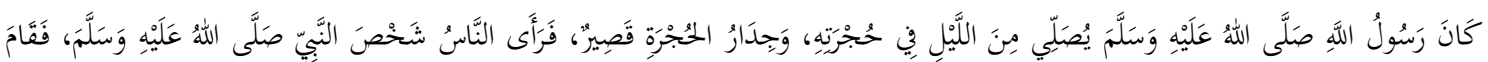

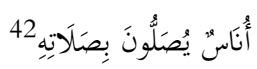

Terjemahnya:

"Pada suatu malam Rasulullah pernah salat di kamarnya, dinding kamar beliau cukup rendah hingga orang-orang pun melihat sosok Nabi. Orang-orang pun berdiri dan shalat bermakmum kepada beliau." (HR. al-Bukhari dan Muslim).

Dapat dijelaskan bahwa pada hadis ini, dengan jelas disebutkan bahwa dinding pemisah antara kamar Nabi dan masjid sangat rendah. Imam al-Syafi'i bahkan menganggap dinding yang demikian sama seperti tiang masjid, sehingga bukan suatu pemisah yang berarti. Kondisi salat berjemaahnya juga masih dalam satu masjid yang utuh, berbeda dengan yang dipraktikkan komunitas salat Jumat virtual di Indonesia mereka salat di rumah masing-masing termasuk imamnya.

Imam Malik ketika membolehkan salat Jumat di luar masjid sangat jelas mempersyaratkan jika masjid tersebut telah penuh dan tidak mampu menampung jamaah $^{43}$. Sedangkan kondisi hari ini, ketika puncak masa pandemi salat Jumat di masjid bahkan ditiadakan.

Dalil atau hadis perintah untuk salat di rumah masing-masing atau di tempat singgah (ketika safar) juga tidak relevan digunakan karena hadis tersebut justru dijadikan oleh ulama Islam sebagai dalil rukhsah meninggalkan salat Jumat dan menggantikan dengan salat Zuhur, di mana orang yang bersafar tidak wajib melaksanakan ibadah salat Jumat ${ }^{44}$.

Persoalan pelaksanaan salat berjemaah secara tidak langsung di mana imam dan makmum tidak berada pada satu tempat yang sama dalam kesatuan yang hakiki telah ada sebelumnya berbarengan dengan penemuan dan penggunaan teknologi radio dan televisi. Lembaga Fatwa Mesir atau Dār al-Iftà' al-Mishriyyah sebagai institusi keagamaan resmi di Mesir yang didirikan tahun $1311 \mathrm{H}$ atau bertepatan dengan tahun $1895 \mathrm{M}$, pernah mengeluarkan fatwa terkait salat Jumat secara individu dengan mendengarkan radio. Nas fatwa dengan tarikh bulan Rabiulakhir tahun $1369 \mathrm{H}$ atau Februari 1950 M yang tertandatangani oleh Mufti Syekh Hasanain Muhammad Makhluf adalah,

Terjemahnya:

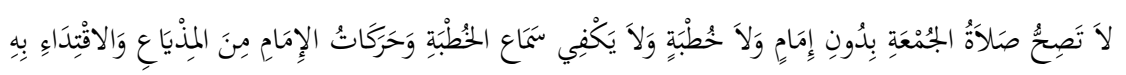

\footnotetext{
${ }^{42}$ Muhammad bin Ismail al-Bukhari, Sahih al-Bukhari, vol 1, hadis no. 729, h 146. Muslim bin al-Hajjaj alNaisaburi, Sahih Muslim, vol 1, hadis no. 781, 539.

${ }^{43}$ Malik bin Anas, al-Mudawwanah, vol. 1, (Cet. I, Darul Kutub Ilmiyah, 1415 H), 232.

${ }^{44}$ Ibnu Batthal; Ali bin Khalaf, Syarah Sahih al-Bukhari, vol. 2, (Riyadh, Cet. II, Maktabah al-Rusyd, 1423 H), 493.
} 


\section{BUSTANUL FUQAHA: \\ JURNAL BIDANG HUKUM ISLAM \\ Vol. 2 No. 1 (2021): Hal. 110-129 \\ EISSN: 2723-6021 \\ Website: https://journal.stiba.ac.id}

"Tidak sah salat Jumat tanpa kehadiran imam dan tanpa khotbah, tidak cukup mendengarkan dan mengikuti khotbah dan gerakan imam dari radio"45.

Setelah 73 tahun (dalam hitungan hijriah) pertanyaan tersebut disampaikan, wasilah dan alat komunikasi terus berkembang pesat. Perangkat komunikasi pada masa sekarang memberikan layanan tambahan, di mana komunikasi terjadi secara langsung atau waktu nyata (real time).

Beberapa lembaga resmi ulama dan ormas Islam baik di dalam maupun luar negeri telah mengeluarkan fatwa terkait pelaksanaan salat Jumat daring, di antaranya:

1. Persatuan Ulama Muslim Internasional (International Union for Muslims Scholars). Nūruddīn al-Khadimī pada laman website resmi Persatuan Ulama Muslim Internasional (International Union for Muslims Scholars) menegaskan pelarangan pelaksanaan salat Jumat jarak jauh melalui wasilah internet dengan argumen sebagai berikut ${ }^{46}$ :

a. tidak memenuhi syarat kesatuan tempat secara hakiki.

b. syariat Islam telah memberikan badal ketika ada uzur untuk melaksanakan salat Jumat yaitu salat Zuhur, dan dalilnya bersifat nas syar' $\bar{\imath}$ dan qath ' $\bar{\imath}$. Tidak boleh mengabaikan rukhsah tersebut karena merupakan wujud rahmat dan kasih sayang Allah Ta'āla.

c. salat Jumat dengan berkumpul secara hakiki adalah ijmak sahabat Nabi dan disepakati oleh semua mazhab fikih.

2. Lembaga Fatwa Mesir (Dār al-Iftā' Al-Mishriyyah). Lembaga ini telah mengeluarkan fatwa pada bulan Maret 2020. Muhammad Mukhtar Jum'ah, mewakili Lembaga Fatwa Mesir (Dār al-Iftā' Al-Mishriyyah), menegaskan bahwa salat Jumat dengan mengunakan wasilah radio, televisi dan koneksi internet adalah tidak sah. ${ }^{47}$ Ketika masjid tidak melaksanakan salat Jumat, muazin ketika azan mengucapkan,

$$
\text { ألا صلوا في بيوتكم ظهرًا.. ألا صلوا في رحالكم ظهرًا }
$$

Terjemahnya:

"Salatlah di rumah kalian, salat Zuhur, salatlah di tempat kalian, salat Zuhur."

3. Pimpinan Pusat Muhammadiyah. Majelis Tarjih dan Tajdid Pimpinan Pusat Muhammadiyah telah mengeluarkan pandangan bahwa: ${ }^{48}$

a. salat Jumat adalah ibadah mahdah yang wajib dilaksanakan sesuai ketentuan yang dituntunkan oleh Nabi Muhammad saw. Segala sesuatu dalam ibadah maḥdah yang dilakukan di luar tuntunan Nabi Muhammad saw. tidak

${ }^{45}$ Dar al-Ifta al-Mishriyyah, vol. 1, dalam al-Maktabah al-Syamilah ver.3.48, 1431 H, 25.

${ }^{46}$ International Union for Muslims Scholars, لماذا لا أصلي الجمعة أمام التلفزة والراديو والأنترنت؟ https://iumsonline.org/ar/ContentDetails.aspx?ID=11157, diakses pada tanggal 23 Maret 2021.

${ }^{47}$ Alatreeq, هل يجوز صلاة الجمعة عبر الانترنت؟.. وزير الأوقاف يجيب, https://www.altreeq.com/126977, diakses pada tanggal 23 Maret 2021.

48 Fatwa Tarjih, Shalat Jumat Online, Bagaimana Hukumnya?, https://fatwatarjih.or.id/hukum-shalatjumat-online/, diakses pada tanggal 23 Maret 2021. 


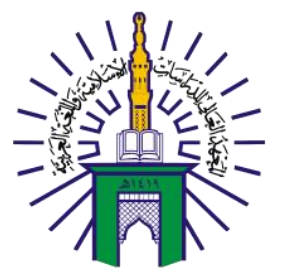

\section{BUSTANUL FUQAHA: \\ JURNAL BIDANG HUKUM ISLAM \\ Vol. 2 No. 1 (2021): Hal. 110-129 \\ EISSN: 2723-6021 \\ Website: https://journal.stiba.ac.id}

dapat dibenarkan. Salat Jumat hukumnya wajib dikerjakan, sehingga apabila terjadi suatu kondisi yang mengakibatkan tidak dapat terlaksananya salat Jumat, kewajiban salat Jumat menjadi gugur dan diganti dengan salat Zuhur. Dalam keadaan darurat karena pandemi COVID-19 ini, jika hendak mendirikan salat Jumat, dapat dilaksanakan secara terbatas di rumah atau tempat lainnya selain masjid atau dapat melaksanakan salat Jumat di masjid secara bergantian (gelombang) dengan tetap menjaga protokol kesehatan secara sangat ketat;

b. praktik salat Jumat secara online, walaupun itu persoalan $i j t i h \bar{a} d \bar{l}$, namun ada ketentuan salat Jumat yang tidak dapat tercapai dalam praktik salat Jumat secara online, yaitu adanya kesatuan tempat secara hakiki (nyata), ketersambungan jemaah, pengaturan posisi imam dan makmum yang sesuai dengan ketentuan salat jemaah (makmum berada di belakang imam) serta keutamaan-keutamaan salat Jumat. Di samping itu, salat Jumat yang dilakukan secara online justru lebih memberi kesulitan baru karena mengharuskan ketersediaan serangkaian perangkat online daripada menggantinya dengan salat Zuhur;

c. sejauh penelusuran terhadap berbagai literatur, Majelis Tarjih dan Tajdid belum menemukan dalil atau alasan yang kuat untuk mengganti salat Jumat dengan salat Jumat secara online. Oleh karena itu, dengan tanpa mengurangi rasa hormat terhadap pendapat yang berbeda, Majelis Tarjih dan Tajdid belum dapat menerima pelaksanaan salat Jumat secara online.

\section{PENUTUP}

Fenomena pelaksanaan salat Jumat daring sebagai alternatif ibadah oleh sebagian komunitas masyarakat di masa pandemi COVID-19 merupakan salah satu fenomena terkini yang patut untuk dicermati, khususnya dalam perspektif hukum Islam. Hal ini karena secara formal, pelaksanaan salat Jumat harus memenuhi syarat-syarat sahnya, sebagaimana yang telah dicontohkan oleh Nabi Muhammad dan dirumuskan oleh para ulama mujtahid. Berdasarkan hasil analisis dan pembahasan penelitian, dapat disimpulkan beberapa hal sebagai berikut:

1. Salat Jumat adalah ibadah wajib berlandaskan Al-Quran, sunah dan ijmak. Imam al-Syafi'i menukilkan ijmak dari generasi ke generasi kaum muslimin tentang kewajiban salat Jumat sebagaimana validnya penukilan kewajiban empat rakaat salat Zuhur. Sebagaimana salat fardu lima waktu, salat Jumat harus memenuhi rukun-rukun dan syarat-syaratnya. Ada tambahan yang merupakan kekhususan salat Jumat, antara lain: dipersyaratkan hal-hal tambahan untuk keabsahannya, dipersyaratkan untuk menentukan siapa yang wajib melaksanakannya, dan adabadab yang disyariatkan dalam pelaksanaannya;

2. Pelaksanaan salat Jumat daring adalah tidak sah. Setidaknya, hal ini dapat ditinjau dari dua aspek; pertama, aspek prinsip dasar dan tujuan diturunkan syariat Islam 


\section{BUSTANUL FUQAHA: \\ JURNAL BIDANG HUKUM ISLAM \\ Vol. 2 No. 1 (2021): Hal. 110-129 \\ EISSN: 2723-6021 \\ Website: https://journal.stiba.ac.id}

(maqūsșid al-syarī'ah), di mana menjaga dinul-Islam terkait pokok ibadah diwujudkan dalam model ibadah seperti, iman, kalimat syahadat, salat, zakat puasa dan haji, sementara menjaga keberlangsungan jiwa dan akal adalah pokok 'adāt (adat) yang diwujudkan dengan aktifitas seperti makan, minum, pakaian dan tempat tinggal, untuk menjaga keberlangsungan jiwa dan akal manusia. Menjaga ibadah salat sesuai dengan sunah Nabi Muhammad saw. menjadi bagian dari hifzu al-dīn (menjaga agama, sehingga tidak tepat jika ada yang berupaya mengubah pola ibadah salat Jumat yang hukum asalnya merupakan satu bangunan yang utuh. Syariat Islam telah memberikan rukhsah bagi setiap muslim yang wajib atasnya salat Jumat untuk menggantinya dengan salat Zuhur sebanyak empat rakaat dan tidak perlu berkumpul dengan orang banyak ketika terdapat hal yang menghalanginya; Kedua, aspek tinjauan fikih Islam. Salat Jumat mensyaratkan adanya jemaah salat dan tidak sah dilakukan secara individu-individu, di mana imam dan makmun harus berada pada satu tempat secara hakiki. Menganalogikan ibadah salat Jumat online dengan akad nikah online adalah tidak tepat. Hal ini karena hukum kias harus dianalogikan kepada hukum asal yang ada dalilnya secara langsung dan tidak boleh kepada produk hukum atau hasil kias lainnya. Hadis yang menyebutkan bahwa seluruh bumi adalah suci dan boleh dijadikan tempat sujud dan masjid, secara eksplisit menunjukkan bolehnya salat di mana saja selama dapat dipastikan tempat sujudnya bersih dari najis, termasuk salat di rumah masingmasing. Tidak ada lafaz dalam hadis yang menyatakan sahnya salat berjemaah atau salat Jumat sejumlah orang dengan kondisi setiap individu di tempat berbeda-beda atau bumi yang berbeda-beda.

Rekomendasi yang dapat disampaikan terkait dengan hal ini adalah:

1. Kaum muslimin hendaknya senantiasa merujuk kepada para ulama dalam memahami setiap persoalan agama. Sekalipun fatwa ulama tidak bersifat mengikat dan tidak mempunyai sanksi duniawi, akan tetapi mempunyai sanksi moril bagi yang tidak memiliki kapasitas untuk berfatwa. Dalam menetapkan hukum persoalan-persoalan terkait kemaslahatan umum, ijtihad kolektif lebih diutamakan daripada ijtihad individual, sebab ijtihad kolektif memiliki landasan dan referensi yang lebih kuat dibandingkan fatwa individual, sehingga lebih meyakinkan dalam menghasilkan produk fatwa yang berkualitas dan efektif menghadirkan kemaslahatan publik ${ }^{49}$.

2. Ketidakpahaman masyarakat tentang prinsip maqāșid al-syarī'ah adalah sebuah "penyakit" yang berpotensi menyebabkan terjadinya penyimpangan dalam agama dan kehidupan bermasyarakat. Persoalan-persoalan syariat yang bersifat kontemporer dan terkait dengan kemaslahatan publik selalu memiliki korelasi

${ }^{49}$ Umar Ali Abu Bakar, Al-Fatāwā al-Fardiyyah wa al-Jama 'iyyah wa al-Muassasiyyah, (Kulliyyah alSyariah wa al-Dirasāt al-Islāmiyyah, Jāmi'ah al-Qașīm, t.th). 


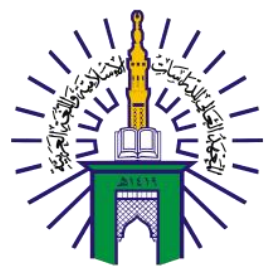

\section{BUSTANUL FUQAHA: \\ JURNAL BIDANG HUKUM ISLAM \\ Vol. 2 No. 1 (2021): Hal. 110-129 \\ EISSN: 2723-6021 \\ Website: https://journal.stiba.ac.id}

dengan prinsip-prinsip maqāṣid al-syarīah. Oleh karenanya, pemerintah diharapkan dapat mengupayakan solusinya, di antaranya melalui sosialisasi terhadap prinsip-prinsip maqāṣid al-syarī'ah kepada masyarakat baik melalui lembaga maupun individu para ulama, mubalig, pakar dan ahli.

\section{DAFTAR PUSTAKA}

Abu Bakar, Umar Ali. Al-Fatāwā al-Fardiyyah wa al-Jama 'iyyah wa al-Muassasiyyah, (Kulliyyah al-Syariah wa al-Dirasāt al-Islāmiyyah, Jāmi'ah al-Qaṣīm, t.th).

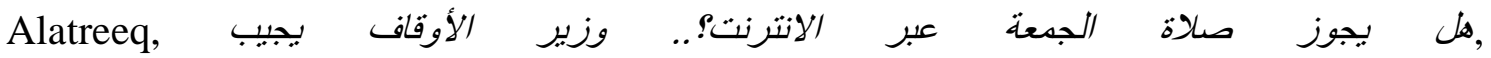
https://www.altreeq.com/126977, diakses pada tanggal 23 Maret 2021.

Al-Bukhari, Al-Jamik as-Shahih, vol. 7, (Beirut: Dār Thuq an-Najāh, 1422 H), no. 5729, h. 130.

Al-Bukhari, Muhammad bin Ismail. Sahih al-Bukhari, vol 1, hadis no. 323, h 74.

Al-Bukhari, Muhammad bin Ismail. Sahih al-Bukhari, vol 1, hadis no. 729, h 146.

Al-Bukhari, Muhammad bin Ismail. Sahih al-Bukhari, vol 2, hadis no. 876, h 2.

Al-Ghumari, Ahmad bin Muhammad bin Shiddiq. Al-Iqna 'bissihah Salatil Jum'ah fil Manzil Khalfa al-Midzyaa’, (Darul Ta`lif, 1375 H), h 33, 40.

Al-Jizani, Muhammad ibn Husain. Tahzib al-Muwāfaqāt (Cet. III; al-Dammam: Dar ibn al-Jauzi, 1430), h. 118.

Al-Maqdis̄i, Abdullah ibn Ahmad ibn Qudāmah, Al-Mugnī, Jilid.2 (t.t; Maktabah alQāhirah, 1968), dalam al-Maktabah al-Syāmilah ver. 3.62 [CD ROM], Muassasah al-Maktabah al-Syāmilah, 2008, h. 250.

Al-Naisaburi, Muslim bin al-Hajjaj. Sahih Muslim, vol 2, hadis no. 855, h 586.

Al-Nawawi, Al-Minhaj Syarh Shahih Muslim bin al-Hajjaj, vol. 1 (Beirut: Dār Ihya atTurāts al-Arabi, 1392 H), h 213.

Al-Nawawi, Raudhatu at-Thalibin wa Umdatu al-Muftiin, vol. 2 (Cet. III. Beirut: alMaktab Al-Islamiy, 1991 M), h 3, 10.

Al-Syafi'i, Muhammad bin Idris. al-Umm, vol. 1 (Beirut: Darul Makrifah, 1991 M), h 217.

Al-Syatibī, Ibrāhīm ibn Mūsa al-Garnāṭ̄ . al-Muwāfaqāt, Jilid. 2 (Cet. II; al-Riyād\}: Dār ibn al-Qayyim li al-Nasyr wa al-Tauzì', 2006), h. 9, 17, 24, 25, 31.

Al-Syatibiy, Al-Muwafaqat, vol. 2 (Cet. I, Dar Ibnu Affan, 1997 H), h 19.

Dār al-Ifta al-Mishriyyah, vol. 1, dalam al-Maktabah al-Syamilah ver.3.48, $1431 \mathrm{H}, \mathrm{h}$ 25.

Fatwa Tarjih, Shalat Jumat Online, Bagaimana Hukumnya?, https://fatwatarjih.or.id/hukum-shalat-jumat-online/, diakses pada tanggal 23 Maret 2021. 


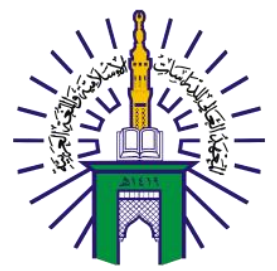

\section{BUSTANUL FUQAHA: \\ JURNAL BIDANG HUKUM ISLAM \\ Vol. 2 No. 1 (2021): Hal. 110-129 \\ EISSN: 2723-6021 \\ Website: https://journal.stiba.ac.id}

Hasibuan, Eko Misbahuddin ., dan Yusram, Muhammad. "Hukum Salat Berjemaah Di Masjid Dengan Saf Terpisah Karena Wabah". BUSTANUL FUQAHA: Jurnal Bidang Hukum Islam 1 no. 2 (2020), 106-24.

Hede, Aswanto Muhammad Takwi., Tempo, Rachmat bin Badani., dan Rafi, Irsyad, "Hukum Pelaksanaan Salat Tarawih Di Rumah Karena Wabah Dan Membaca Al-Qur'an Melalui Mushaf Dan HP Ketika Salat". BUSTANUL FUQAHA: Jurnal Bidang Hukum Islam 1 no. 2(2020), 251-61.

Ibnu Batthal, Ali bin Khalaf, Syarah Sahih al-Bukhari, vol. 2, (Riyadh, Cet. II, Maktabah al-Rusyd, 1423 H), h 493.

International Union for Muslims Scholars, لماذا لو أصلي الجدعة أمام الثلفزة والراديو والأنترنت؟ https://iumsonline.org/ar/ContentDetails.aspx?ID=11157, diakses pada tanggal 23 Maret 2021.

Iskandar, Azwar., Possumah, Bayu Taufiq., dan Aqbar, Khaerul. "Peran Ekonomi dan Keuangan Sosial Islam saat Pandemi Covid-19." SALAM: Jurnal Sosial dan Budaya Syar-i 7, no. 7 (2020): 625-638.

John, W. C., Research Design Pendekatan Kualitatif, Kuantitatif dan Mixed (Yogyakarta: Pustaka Pelajar, 2013).

Kompas TV, Ikhtiar Salat Jumat Online di Tengah Pandemi, https://www.kompas.tv/article/148623/ikhtiar-salat-jumat-online-di-tengahpandemi, diakses pada tanggal 25 Maret 2021.

Kumparan News, Pro dan Kontra di Sejumlah Negara soal Salat Jumat Online, https://kumparan.com/kumparannews/pro-dan-kontra-di-sejumlah-negara-soalsalat-jumat-online-1uuaGwQjgf5. Diakses pada tanggal 25 Maret 2021.

Kumparan, Praktik Salat Jumat Online di Indonesia, https://kumparan.com/kumparannews/praktik-salat-jumat-online-di-indonesia1uvr0MIjMt3/full, diakses pada tanggal 25 Maret 2021.

Mahmuddin, Ronny., Rafi, Irsyad., Aqbar, Khaerul., dan Iskandar, Azwar. "Hukum Menyegerakan Penyerahan Zakat Harta Dan Zakat Fitrah di Saat Pandemi Covid-19”. BUSTANUL FUQAHA: Jurnal Bidang Hukum Islam 1 no. 1 (2020), 125-36.

Malik bin Anas, A-Mudawwanah, vol. 1, (Cet. I, Darul Kutub Ilmiyah, 1415 H), h 232. Muhammad Kumaidi, "Implementasi Kaedah La yunkaru tagayyur al-ahkām bi tagayyuri al-ahkām wa al-Aḥwāl Dalam Ibadah di Masa Pandemi”, Asas 1, No. 1 (2020): 65-82.

Mukran H. Usman, Aswar Aswar, dan Zulfiah Sam. "Covid-19 Dalam Perjalanan Akhir Zaman: Sebab, Dampak Dan Anjuran Syariat Dalam Menghadapinya". BUSTANUL FUQAHA: Jurnal Bidang Hukum Islam 1 no. 1 (2020), 137-55.

Muslim bin al-Hajjaj al-Naisaburi, Sahih Muslim, vol 1, hadis no. 781, h 539. 


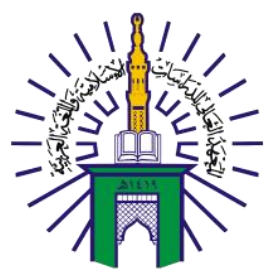

\section{BUSTANUL FUQAHA: \\ JURNAL BIDANG HUKUM ISLAM \\ Vol. 2 No. 1 (2021): Hal. 110-129 \\ EISSN: 2723-6021 \\ Website: https://journal.stiba.ac.id}

Qotadah, Hudzaifah Achmad. "Covid-19: Tinjauan Maqasid Al-Shariah Terhadap Penangguhan Pelaksanaan Ibadah Shalat di Tempat Ibadah (Hifdz al-Nafs Lebih Utama Dari Hifdz al-Din?)," Salam: Jurnal Sosial dan Budaya Syar-i 7, No.7 (2020): h. 659-672.

Shodiq, Shubhan. "Penanganan Covid-19 Dalam Pendekatan Kaidah Fikih dan Ushul Fikih: Analisis Kebijakan Pembatasan Sosial Berskala Besar di Biang Keagamaan," Jurnal: al-Adalah: Jurnal Hukum dan Politik Islam 5, No. 2 (2020): h. 113-134.

Sirajuddin, Sirajuddin,. Salenda, Kasjim., dan Haddade, Abdul Wahid. "Peniadaan Salat Jumat Dalam Surat Edaran Gubernur Sulsel Nomor: 451.11/2057/2020 Selama Pandemi Covid-19 Perspektif Maqāṣid Al-Syarīah". NUKHBATUL 'ULUM: Jurnal Bidang Kajian Islam 6 no. 2 (2020), 289-309.

Sudaryana, Bambang . Metode Penelitian, (Yogyakarta, Deepublish, 2017 M), h. 9.

Sudirman, dan Rasyid, Muhammad Rusdi. "Resolusi Maqasid al-Syariah Terhadap Penanggulangan Virus Covid-19," Tasamuh: Jurnal Studi Islam 12, No. 2 (2020): h. 253-431.

Syandri, Syandri., dan Akbar, Fadhlan. "Penggunaan Masker Penutup Wajah Saat Salat Sebagai Langkah Pencegahan Wabah Coronavirus Covid-19." SALAM: Jurnal Sosial dan Budaya Syar-i 7, no. 3 (2020): 261-268.

Yunta, Akhmad Hanafi Dain, dan Asri. "Hukum Melaksanakan Salat Id Secara Personal (Munfarid) (Sebuah Solusi Pelaksanaan Salat Id di Masa Wabah Covid19)”. BUSTANUL FUQAHA: Jurnal Bidang Hukum Islam 1, no. 2 (2020), 26271.

Yusram, Muhammad. "Azan dan Kaifiatnya di Tengah Wabah Covid-19," BUSTANUL FUQAHA: Jurnal Bidang Hukum Islam 1, no. 2 (2020), 174-96. 